\title{
Effect of temperament of Jersey and Holstein Friesian cows on milk production traits and somatic cell count (Short Communication)
}

Martina Orbán' ${ }^{1}$ Katalin Kovácsné Gaál', Ferenc Pajor², Andrea Szentléleki², Péter Póti², János Tőzsér² and László Gulyás ${ }^{1}$

'Institute of Animal Husbandry, University of West Hungary, Hungary, ${ }^{2}$ Institute of Animal Husbandry, Szent István University, Hungary

\begin{abstract}
The aim of present study was to investigate the relationships between temperament score and milk production, as well as somatic cell count in a herd of Jersey and Holstein Friesian breeds. The temperament of 283 Jersey and 69 Holstein Friesian cows were assessed (scored) by the temperament score test (behaviour of animals was assessed in a 5-score system (1: calm, 5: nervous) while spending 30 s on the scale during weighing). The daily milk yield, fat, protein content and somatic cell count were also investigated in this study. Our investigation did not reveal any correlation between daily milk yield and temperament score. But milk somatic cell count was showed positive moderate relation with the temperament scores of Jersey $\left(r_{\text {rank }}=0.67 ; P=0.0001\right)$ and Holstein Friesian $\left(r_{\text {rank }}=0.66 ; P=0.0001\right)$ cows. Calmer cows had lower somatic cell count (Jersey: $135.40 \times 10^{3} / \mathrm{cm}^{3}$; Holstein Friesian: $176.07 \times 10^{3} / \mathrm{cm}^{3}$ ) compared to the more temperamental cows (Jersey: $540.44 \times 10^{3} / \mathrm{cm}^{3} ; P=0.0001$; Holstein Friesian: $744.91 \times 10^{3} / \mathrm{cm}^{3} ; P=0.0001$, resp.).
\end{abstract}

Keywords: temperament, milk production, somatic cell count, Jersey, Holstein Friesian

\section{Zusammenfassung}

\section{Einfluss des Temperaments von Jersey und Holstein-Friesian Kühen auf Milchleistung und somatische Zellzahl (Kurzmitteilung)}

Untersucht wurde, ob es einen Zusammenhang zwischen Temperament, Milchleistung und somatischer Zellzahl bei Jersey und Holstein-Friesian Kühen gibt. Dazu wurde das Temperament von 283 Jersey und 69 Holstein Friesian Kühen durch einen Test festgestellt, bei dem die Tiere nach einem Fünf-Punkte-Schema (von 1=ruhig bis $5=$ nervös) bewertet wurden. Der Test erfolgte während des Wiegens (Dauer $30 \mathrm{~s}$ ). Außerdem wurden noch tägliche Milchleistung, Fett, Eiweiß und somatische Zellzahl untersucht. Es wurde kein Zusammenhang zwischen Milchleistung und Temperament entdeckt.

Allerdings zeigte sich ein gewisser Zusammenhang zwischen Temprament und somatischer Zellzahl (Jersey: $r_{s}=0,66, P=0,0001$; Holstein Friesian: $\left.r_{s}=0,67, P=0,0001\right)$. Dabei wiesen ruhige

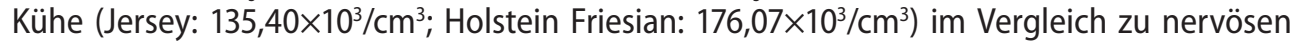


Kühen (Jersey: $540,44 \times 10^{3} / \mathrm{cm}^{3}, P=0,0001$; Holstein Friesian: $744,91 \times 10^{3} / \mathrm{cm}^{3}, P=0,0001$ ) eine niedrigere somatische Zellzahl auf.

Schlüsselwörter: Temperament, Milchproduktion, somatische Zellzahl, Jersey, Holstein Friesian

\section{Introduction}

Behaviour of dairy cows usually referred to as temperament is one of the factors influenced milk production. Temperament is defined as the animal's behavioural response to handling by humans (Burrow 1997). Temperament seems to influence some production traits such as growth rate (Voisinet et al. 1997, Pajor et al. 2008) and immune function (Ivanov et al. 2005). The genetic background of temperament is well known, the estimated heritability of temperament is found 0.25 in Jersey cattle by Visscher \& Goddard (1995). Glenske et al. (2010) found relation a QTL on BTA1 and behaviour of suckler calves.

Several studies have reported positive relationships between dairy temperament score and milk production traits in cows. Mushra et al. (1975), Arave \& Kilgour (1982) revealed linear relationship stands between temperament score and daily and total milk yields, but the relationship with lactation length was not clear. Furthermore, in Bos indicus cows with unfavourable temperament produced less milk and their ability of releasing milk was the worst compared to cows having better temperament (Gupta \& Mishra 1979). But Purcell et al. (1988) and Khana \& Sharma (1988) did not reveal any correlation between milk production and temperament. Although, the majority of studies reports positive relationships between temperament score and milk production, it is not known whether the relationship exists between the cows' temperament and milk somatic cell count.

This study's aim was to investigate the relations between temperament score and milk production traits (such as daily milk yield, fat and protein content) and somatic cell count in Jersey and Holstein Friesian breeds.

\section{Materials and methods}

\section{Experimental design:}

The study was conducted on a dairy cattle Farm in Mosonmagyaróvár (Győr-Moson-Sopron County, Hungary). 283 Jersey (1st lactation: $n=214$, 2nd lactation: $n=69$ ) and 69 Holstein Friesian (1st lactation: $n=57,2$ nd lactation: $n=12$ ) cows were examined daily milk yield, fat and protein composition of milk and somatic cell count.

The animals were kept in loose housing stable with deep litter and nutrition was corn silage-based monodiet in Total Mixed Ration (TMR). The cows milked in $2 \times 12$ SAC milking parlour, 2 times per day has occurred.

The milk samples were collected from animals at morning milking. Fat and protein contents of milk were determined using by MilkoScan device (FT6000 apparatus, Foss Electric, Denmark). The somatic cell count of milk samples was determined by Fossomatic 5000 device (Foss Electric, Denmark) at Livestock Performance Testing Ltd (Gödöllö, Hungary). 


\section{Temperament test}

The temperament test was applied before morning milking in weighing cage towards milking parlour at same day with milk samples collection. Observations were conducted on cows once in third month of lactation (average days: 80). Temperament was measured according to the temperament score test by Trillat et al. (2000). Behaviour of animals was assessed in a 5 -score system at weighing, while spending $30 \mathrm{sec}$ on the scale:

1 calm, no movement,

2 calm with occasional movements,

3 calm with some more movements but without shaking the scale,

4 abrupt episodic movements without shaking the scale,

5 permanent episodic movements and shaking the scale.

\section{Statistical analysis}

Data were analysed with SPSS Statistics 14.0 (SPSS Inc., Chicago, IL, USA) statistical program package using by Spearman's rank correlation, furthermore, the general linear model (GLM) procedure to perform an analysis of variance. The statistical model was as follows:

$$
Y_{i j k}=\mu+A_{i}+B_{j}+C_{k}+e_{i j k}
$$

where $Y_{i j k}$ is the value of the dependent variable, $\mu$ is the overall mean, $A_{i}$ is the effect of breed, $B_{j}$ is the effect of number of lactation, $C_{k}$ is the effect of temperament score and $e_{i j k}$ is the random error.

Significance was taken at an alpha level of 0.05 . Statistical significant effects were further analysed and means were compared using by Tukey test.

\section{Results}

The results of temperament scores, daily milk yield and milk composition, furthermore somatic cell count of milk according to the breeds and number of lactation are demonstrated in Table 1.

Table 1

LS means \pm standard error of temperament score, milk production traits and somatic cell count according to breeds and number of lactation

\begin{tabular}{|c|c|c|c|c|c|c|}
\hline \multirow[t]{2}{*}{ Parameters } & \multicolumn{2}{|c|}{ Breed } & \multicolumn{2}{|c|}{ Number of lactation } & \multicolumn{2}{|c|}{ Significance } \\
\hline & $\begin{array}{l}\text { Jersey } \\
\mathrm{n}=283\end{array}$ & $\begin{array}{l}\text { Holstein Friesian } \\
\qquad \mathrm{n}=69\end{array}$ & $\begin{array}{l}\text { 1st lactation } \\
\mathrm{n}=271\end{array}$ & $\begin{array}{c}\text { 2nd lactation } \\
\qquad \mathrm{n}=81\end{array}$ & Breed & $\begin{array}{l}\text { No of } \\
\text { lactation }\end{array}$ \\
\hline Temperament score & $1.53 \pm 0.04$ & $2.69 \pm 0.08$ & $2.16 \pm 0.05$ & $2.08 \pm 0.08$ & 0.0001 & 0.325 \\
\hline Daily milk yield, kg & $18.16 \pm 0.26$ & $23.64 \pm 0.49$ & $19.27 \pm 0.28$ & $22.53 \pm 0.46$ & 0.0001 & 0.0001 \\
\hline Fat, $\%$ & $5.92 \pm 0.06$ & $3.66 \pm 0.11$ & $5.01 \pm 0.06$ & $4.57 \pm 0.11$ & 0.0001 & 0.0001 \\
\hline Protein, \% & $4.43 \pm 0.03$ & $3.43 \pm 0.05$ & $4.08 \pm 0.03$ & $3.77 \pm 0.05$ & 0.001 & 0.0001 \\
\hline SCClog & $5.23 \pm 0.03$ & $5.39 \pm 0.05$ & $5.35 \pm 0.03$ & $5.27 \pm 0.05$ & 0.003 & 0.113 \\
\hline
\end{tabular}

The temperament score of cows is not affected by number of lactation in either of breeds. Therefore the temperament scores data of cows of different lactation numbers were contracted in both breeds. The results showed significant differences in temperament score between two breeds $(P=0.0001)$. The Jersey cows were calmer than Holstein Friesian cows. 
Based on the temperament ranking, $50.9 \%$ of Jersey cows got $» 1$ « score (calm animals), $42.8 \%$ of cows got $" 2$ « score and $6.3 \%$ of cows got »3 3 score. Results of daily milk yield, fat and protein composition of milk and somatic cell count of milk of Jersey cows according to the temperament scores are demonstrated in Table 2.

Table 2

LS means \pm standard error of Jersey cows milk production data according to temperament scores

\begin{tabular}{lcccc}
\hline Parameters & 1 & Temperament score & Significance \\
\hline $\mathrm{n}$ & 144 & 121 & 18 & \\
$\%$ & 50.9 & 42.8 & 6.3 & \\
Daily milk yield, kg & $17.72 \pm 0.33$ & $16.94 \pm 0.36$ & $16.64 \pm 0.92$ & 0.206 \\
Fat, \% & $5.99 \pm 0.08$ & $6.05 \pm 0.09$ & $6.16 \pm 0.22$ & 0.734 \\
Protein, \% & $4.53 \pm 0.04$ & $4.49 \pm 0.04$ & $4.50 \pm 0.11$ & 0.769 \\
SCClog & $5.00 \pm 0.03^{\mathrm{a}}$ & $5.46 \pm 0.03^{\mathrm{b}}$ & $5.71 \pm 0.07^{\mathrm{c}}$ & 0.0001 \\
\hline
\end{tabular}

1: calm, no movement, 2: calm with occasional movements, 3: calm with some more movements but without shaking the scale; abcDifferent letters in a row denote significant differences $(P<0.05)$.

The daily milk yield and composition not detected differences among temperament scores. But the milk somatic cell count showed high differences among temperament scores. The calmer cows had a lower $(P=0.0001)$ somatic cell count $\left(5.0 \mathrm{log} / \mathrm{cm}^{3}\right)$ compared to the more temperamental cows $\left(5.7 \mathrm{log} / \mathrm{cm}^{3}\right)$. The milk somatic cell count showed medium relationship with the temperament scores $\left(r_{\text {rank }}=0.67 ; P=0.0001\right)$.

After the temperament ranking, $1.5 \%$ of Holstein Friesian cows got »1 «score (calm animals), $40.6 \%$ of cows got $» 2$ «score, $42.0 \%$ of cows got $» 3$ « score and $15.9 \%$ of cows got » 4 « score. Results of daily milk yield, fat and protein composition of milk and somatic cell count of milk of Holstein Friesian cows according to the temperament scores are demonstrated in Table 3.

Table 3

LS means \pm standard error of Holstein Friesian cows milk production data according to temperament scores

\begin{tabular}{lccccc}
\hline Parameters & \multicolumn{5}{c}{ Temperament score } \\
& 1 & 2 & 3 & 4 & Significance \\
\hline $\mathrm{n}$ & 1 & 28 & 29 & 11 & \\
$\%$ & 1.5 & 40.6 & 42.0 & 15.9 & \\
Daily milk yield, kg & 25.2 & $23.39 \pm 0.86$ & $21.95 \pm 0.84$ & $21.95 \pm 1.37$ & 0.442 \\
Fat, \% & 3.61 & $3.74 \pm 0.13$ & $3.91 \pm 0.13$ & $3.74 \pm 0.21$ & 0.611 \\
Protein, \% & 3.49 & $3.51 \pm 0.08$ & $3.58 \pm 0.07$ & $3.43 \pm 0.12$ & 0.552 \\
SCClog & 4.81 & $5.09 \pm 0.06 \mathrm{a}$ & $5.60 \pm 0.06 \mathrm{~b}$ & $5.83 \pm 0.10 \mathrm{~b}$ & 0.0001 \\
\hline
\end{tabular}

1: calm, no movement, 2: calm with occasional movements, 3: calm with some more movements but without shaking the scale, 4 : abrupt episodic movements without shaking the scale, ${ }^{a b}$ Different letters in a row denote significant differences $(P<0.05)$.

No correlation was found between daily milk yield and temperament score. On the contrary, the calmer cows had a lower $(P=0.0001)$ somatic cell count $\left(5.1 \mathrm{log} / \mathrm{cm}^{3}\right)$ compared with the more temperamental cows $\left(5.8 \mathrm{log} / \mathrm{cm}^{3}\right)$. The milk somatic cell count showed medium relationship with the temperament scores $\left(r_{\text {rank }}=0.66 ; P=0.0001\right)$. 


\section{Discussion}

During investigation, did not found any relation between daily milk yield and temperament score, which is in accordance with some observations by Purcell et al. (1988) and Khanna \& Sharma (1988). Other studies (such as Mushra et al. 1975, Arave \& Kilgour 1982) have shown that temperament has great effect on milk production. On the contrast, the milk somatic cell count showed significant, medium relationship with the temperament scores, the calmer cows had lower somatic cell count. The repeatability of temperament scores and somatic cell count was about 0.31-0.44 (Halloway \& Johnston 2003) and 0.26-0.40 (Kennedy et al. 1982). It suggested that multiple measurements are necessary; but the demonstrated values draw attention to the importance of temperament. It is well known that the milk somatic cell count is affected by many factors, such as immune system status of animal. The previous result was suggested that temperamental animal has higher baseline cortisol concentration (Pajor et al. 2010). The higher baseline cortisol inhibits the immune system by altering the function of the HPA axis (Yotova et al. 2004). It has been shown that a deficiency of immune system has a negative effect on somatic cell count in milk. Manteuffel (2002) summarising the regulation of HPA axis and its impact on metabolism and animal welfare.

Summarised the results, this study suggested that the more temperamental cows produced more milk somatic cell count under milking period compared with calm cows. Finally, calmer cows produced more hygienic milk then temperamental animals. These results indicate that temperament test application is positive benefits for dairy cattle breeders, e.g. calm animals can reduce somatic cell counts and increased hygienic value of milk.

\section{References}

Arave CW, Kilgour R (1982) Differences in grazing and milking behaviour in high and low breeding index cows. Proc N Z Soc Anim Prod 42, 65-67

Burrow HM (1997) Measurement of temperament and their relationship with performance traits of beef cattle. Anim Breed Abstr 65, 478-495

Glenske K, Brandt H, Prinzenberg EM, Gauly M, Erhardt G (2010) Verification of a QTL on BTA1 for temperament in German Simmental and German Angus calves. Arch Tierz 53, 388-392

Gupta SC, Mishra RR (1979) Temperament and its effect on milking ability of Karan Swiss cows. Proc. 20th Int Dairy Congr, Paris, France, 130

Halloway DR, Johnston DJ (2003) Evaluation of flight time and crush score as measures of temperament in Angus cattle. Proc. 15th Conf, Association for the Advancement of Animal Breeding and Genetics, Melbourne, Australia, 7-11 July 2003, 261-264

Ivanov ID, Djorbineva M, Sotirov L, Tanchev S (2005) Influence of fearfulness on lysozyme and complement concentrations in dairy sheep. Rev Med Vet 156, 445-448

Kennedy BW, Sethar MS, Tong AKW, Moxley JE, Downey BR (1982) Environmental factors influencing test-day somatic cell counts in Holsteins. J Dairy Sci 65, 2. 275-280

Khanna AS, Sharma JS (1988) Association of dairy temperament score with performance in some Indian breeds and crossbred cattle. Ind J Anim Sci 58, 237-242

Manteuffel G (2002) Central nervous regulation of the hypothalamic-pituitary-adrenal axis and its impact on fertility, immunity, metabolism and animal welfare - a review. Arch Tierz 45, 575-595

Mushra RR, Chauhan RS, Gupta SC (1975) Studies of dairy temperament of Karan Swis Cows, Ind J Dairy Sci 28, 85-88 
Pajor F, Szentléleki A, Láczó E, Tőzsér J, Póti P (2008) The effect of temperament on weight gain of Hungarian Merino, German Merino and German Blackhead lambs. Arch Tierz 51, 247-254

Pajor F, Murányi A, Szentléleki A, Tőzsér J, Póti P (2010) Effect of temperament of ewes on their maternal ability and their lambs' postweaning traits in Tsigai breed. Arch Tierz 53, 4 465-474

Purcell D, Arave CW, Walters JL (1988) Relationship of three measures of behaviour to milk production. Appl Anim Behav Sci 21, 307-313

Trillat G, Boissy A, Boivin X, Monin G, Sapa J, Mormende P, Neindre LP (2000) Relations between the well-being of cattle and meat characteristics. Final Report-June. INRA, Theix, France, 1-33 [in French]

Visscher PM, Goddard ME (1995) Genetic parameters for milk yield, survival, workability, and type traits for Australian dairy cattle. J Dairy Sci 78, 205-220

Voisinet BD, Grandin T, Tatum JD, O'Connor SF, Struthers JJ (1997) Feedlot cattle with calm temperaments have higher daily gains than cattle excitable temperaments. J Anim Sci 75, 892-896

Yotova IT, Sotirov LK, Stoyanchev TK, Bozakova NA, Yarkov DJ, Stoyanchev KT, Oblakova MG, Lalev MT (2004) Study on the level of natural humoral immunity in turkey-broilers bred on two floor types. Bulg J Vet Med $7,51-56$

Received 10 March 2011, accepted 23 August 2011.

Corresponding author:

Péter Póti

email: poti.peter@mkk.szie.hu

Szent István University, Faculty of Agricultural and Environmental Sciences, Institute of Animal Husbandry, H-2103 Gödöllö, Páter Károly 1., Hungary 